\title{
Genocide in Australia
}

\author{
Andrew M arkus
}

\begin{abstract}
A number of scholars - notably Tony Barta, Colin Tatz, Dirk M oses ${ }^{1}$ - have in recent years attempted to apply the concept of genocide to the conflict between European and Indigenous peoples in Australia. The definition of genocide is necessarily central to such analysis, with the definition contained in the 1948 United Nations Convention on the Prevention and Punishment of the Crime of Genocide being most often used. It defines genocide as any of the following acts committed with intent to destroy, in whole or in part, a national, ethnical, racial or religious group, as such:

(a) killing members of the group;

(b) causing serious bodily or mental harm to members of the group;

(c) deliberately inflicting on the group conditions of life calculated to bring about its physical destruction in whole or in part;

(d) imposing measures intended to prevent births within the group;

(e) forcibly transferring children of the group to another group.
\end{abstract}

There is recognition that the convention - the result of political compromise between the western democracies and Stal inist Russia - has serious weaknesses, yet it nonetheless remains the key reference point. Colin Tat defends its continued use in historical analysis on the ground that it is the one means of maintaining a 'universally accepted yardstick ... a definition, however flawed, [which] is the one defined in international law'. He is concerned that 'if we venture into this realm of improved definitions, we will have no universally accepted yardstick'.

There is, however, a confusion in this line of reasoning between different, although to some degree overlapping or interconnected, purposes to be served by definition: to serve legal ends, such as providing the basis for prosecution of war criminals and to establish claims for compensation; to serve the political ends of specific racial or ethnic groups, as in attempts to develop new perspectives on history and reshape dominant discourses; and the heuristic function, to 'help us to better understand the world ${ }^{\prime}{ }^{3}$ In my view the definition contained in the Genocide Convention is a blunt

1. Tony Barta 1985, 'A fter the Holocaust: Consciousness of genocide in A ustralia', A ustral ian Journal of Politics and H istory, 31(1): 154-61; Colin Tatz, 'Genocide in Australia', A IA TSIS Research Discussion Paper no. 8, AIATSIS, Canberra; A. Dirk Moses 2000, 'An antipodean genocide? The origins of the genocidal moment in the colonization of Australia', Journal of G enocide Research, 2(1): 89-106

2. Tatz, 'Genocide in Australia': 4-5. 
instrument, not designed to permit subtle - even unsubtle - differentiation of experience, which should be one of the aims of heuristic classification. Uncritical use of this definition was more understandable at a time when attempts were first made in the 1980s to better understand the Australian experience, than today. It is now timeto move beyond such undiscriminating classification to one with a greater power to distinguish between allied but nonetheless different forms of genocidal action.

Yehuda Bauer, a leading authority on the Holocaust, argues that the definition in the Genocide Convention contains a fundamental flaw, the subsuming of two distinct phenomena, 'radical and murderous denationalization accompanied by mass murder, which destroys a group as an entity but leaves many or most of the individuals composing it alive' and 'murder of every single individual of the targeted group'. ${ }^{4} \mathrm{~A}$ further problem, noted by other commentators, is the failure to distinguish between policies which aim at cultural suppression and those which seek to achieve their ends through physical destruction. Following these lines of reasoning, it is possible to distinguish three forms of state action:

Ethnocide: the attempt to bring about the disappearance of an ethnic or racial group by suppression of its culture, language, and religion, but stopping short of physical destruction. ${ }^{5}$

G enocide: the attempt to bring about the disappearance of an ethnic or racial group by deliberately inflicting on the group conditions of life calculated to bring about its partial physical destruction and including selective mass killing.

H olocaust: the attempt to bring about the disappearance of an ethnic or racial group by deliberately inflicting on the group conditions of life calculated to bring about its total physical destruction and including killing all members of the group. ${ }^{6}$

These categories are suggested as working definitions to enable critical scrutiny of evidence, a process currently impeded by, on the one hand, too broad a definition which enables a range of discrete events extending to policies of assimilation to be labelled as genocide, while on the other hand too narrow definition rules out serious examination of the historical record because genocide is seen to be equated with an event at the maximal end of a possible range. In the following I consider the Australian experience in the context of the maximal, German policy towards Jews from 1933 to 1945, not to dismiss out-of-hand the applicability of the genocide concept (which is the point reached by some ${ }^{7}$ ) but to provide the means for evaluation, to develop understanding of both commonality and difference. Some who have employed the broad category of genocide might find use in a fuller understanding of the Nazi regime. While embarking on comparison based on historical examples, I am not attempting to measure one people's suffering against another's, necessarily a spurious undertaking -

3. Yehuda Bauer 2001, Rethinking the H olocaust, Yale University Press, N ew Haven: 8.

4. Bauer 2001: 9.

5. See Chalk and Jonassohn 1990: 23; Charny 1999, Encyclopedia of genocide, ABC-Clio, Santa Barbara vol 1: 9 .

6. See Bauer, Rethinking the H ol ocaust: 10,12

7. In this vein, see Inga Clendinnen 2001, 'First contact', in Q uarterly Essay, no. 2: 106 (first published in the A ustralian's R eview of Books, May 2001). 
likened by one commentator as a quest for the 'gold medal in the Victimisation Olympics'. ${ }^{8}$ As Bauer writes, 'no gradation of human suffering is possible'.

The treatment of Jews in Nazi Germany, and then within the wider sphere of German control, passed through a number of distinct stages. First, beginning in 1933, Jews were debarred from employment in position of public significance: thus (with some temporary exceptions), they were denied employment in the public service, areas of medicine and the law, theatre, the press and arts. This was the beginning of a process of formal segregation of the Jews of Nazi Germany through the enactment of legislation, a reversal of the nineteenth century process of emancipation by which they had come to a position of full political and legal equality.

During the second stage, dated from 1935, there was a formal withdrawal of citizenship and segregation was extended. The rationale of the publicly proclaimed state ideology rested on the belief that race was the most important determinant of national life. In furtherance of the task of racial purification it was essential to purge the nation of inferior and alien racial elements, as well as to improve the A ryan genetic stock by eugenic measures. Thus, also in 1935, Jews were prevented from marrying A ryans and sexual contact between the peoples was prohibited under the criminal law. Financial and other inducements were provided to encourage procreation of 'superior' Aryan types, while those with disabilities were forcibly sterilised and babies born with deformities were killed.

The third stage was reached in 1938. Having excluded Jews from public life, the regimenow embarked upon the removal of Jews from the economy. A series of 'A ryanisation' measures, requiring Jewish businessmen to sell their concerns to Aryan Germans, produced a rapid pauperisation of the Jewish community. Even before the outbreak of war in 1939 members of a community that had been distinguished by its achievements in the worlds of learning, culture and commerce now found themselves unable to earn a livelihood. 1938 also witnessed escalation of violent attacks on Jews in the streets, the vandalisation of shops and the burning of synagogues. By the end of the year Jews besieged foreign embassies in the hope of securing a visa - the one means of escape. $^{9}$

With the outbreak of war and the occupation of Poland and other countries with large Jewish populations the number of Jews under German control greatly increased. Now segregation took on a geographical dimension, the fourth stage of discrimination. Jews were forced to relocate in specially designated locations, called ghettos. Within the ghettos in the east, which became closed to the outside world, $N$ azi authorities adopted a deliberate policy of overcrowding and starvation, denial of medicine and other neces-

8. Peter N ovick 1999, The H olocaust in A merican life, Houghton Mifflin, Boston: 195.

9. The best study of the years to the outbreak of war is Saul Friedlander 1997, N azi Germany and the Jews: the years of persecution 1933-39, Weidenfeld \& N icolson, London; for a briefer coverage, see Leni Yahil 1987, The H olocaust: the fate of European Jewry, Oxford University Press, Oxford, English edition 1990. 
sities of life, leading to rising death toll. In the Warsaw ghetto, with a Jewish population at its peak of over 400000 , the annual death toll from these 'natural' causes was over ten per cent of the total Jewish population in 1941 and $1942 .{ }^{10}$ Every morning burial squads would be seen in the streets, collecting the bodies of the several hundred who had died the previous day.

The fifth stage began shortly after the invasion of Russia in June 1941. From midAugust German murder squads (called Einsatzgruppen) rounded up the Jewish populations of small and large towns and when sufficient number had been collected marched them to killing fields. Those refusing to move were shot on the spot. On arrival pits were dug by those about to die. The victims, in family groups, were required to remove their clothing, then systematically killed by shooting. At the peak of the killings, September 1942, some 192000 were murdered; at one location, Babi Yar (on the outskirts of Kiev) 33771 were killed over two days, 29-30 September. By the end of 1942 over 618000 had been shot. $^{11}$

The sixth and final stage involved industrialised murder at six killing sites, the first of which become operational at Chelmno in December 1941. The preferred killing method was gassing - at Chelmno by carbon monoxide fed into the rear compartment of specially designed trucks into which 20 or 30, sometimes more, persons were locked; at three other killing centres by carbon monoxide produced by engines in fixed installations, with the gas fed into sealed rooms; and at two killing centres by the poison hydrogen cyanide ( $\mathrm{HCN}$ ), marketed under the commercial name Zyklon B. The total number killed at these camps numbered in the millions: the largest toll was at Auchwit-Birkenau, where it is estimated that at least one million Jews were killed from March 1942 to N ovember 1944. ${ }^{12}$

Consideration of the Australian contact experience will be undertaken with reference to two main phases, the period of dispossession when the main objective was to remove A boriginal people from their land to pave the way for European economic activity, and a second phase when policy sought to deal with the surviving Aboriginal populations.

A boriginal people resisting the takeover of their lands were met with armed force. Conflict was particularly intense in Van Diemen's Land (Tasmania) in the 1820s and subsequently in northern regions of $\mathrm{New}$ South Wales, in Queensland and central Australia. Raymond Evans and Bill Thorpe have recently assembled evidence from some regions of the continent where 'mass murder' of Aboriginal people occurred; killing, they write, was 'a way of life, executed by a minority of perpetrators, tolerated by a settler majority, and winked at by [the] ... state'. ${ }^{13}$ In some regions governments maintained a paramilitary force to deal with A boriginal resistance, most clearly evident

10. Israel Gutman (ed.) 1990, Encycl opedia of the H olocaust, Macmillan, N ew York: 1609.

11. Yahil, The H olocaust: 270; Martin Gilbert 1987, The H olocaust, Fontana, London: 202-6.

12. Deborah Dwork and Robert Jan van Pelt, A uschwitz: 1270 to the present, W.W. Norton, New York: 343.

13. Ray Evans and Bill Thorpe 2001, 'The massacre of history', The A ge, 7July Saturday Extra: 1, 6. 
in the Queensland Native Police. In earlier work Evans has documented the environment of terror which governed the lives of A boriginal people in colonial Queensland. ${ }^{14}$

Yet armed attacks on A borigines were typically carried out by 'settler-invaders' and were in the nature of vigilante actions - sporadic, localised, retaliatory. ${ }^{15}$ Governments did not conceptualise or sanction mass killing in the nineteenth century, although some groups of pastoralists did. While not aiming at physical extermination in the short term, policy assumed without question the right to destroy Aboriginal civilisation through expropriation of land, essential to its existence.

In a pioneering article Tony Barta sought to apply Raphael Lemkin's 1944 conceptual isation of genocide to the process of dispossession in Australia. Lemkin wrote that genocide signified:

A coordinated plan of different actions aimed at the destruction of essential foundations of life on national groups, with the aim of annihilating the groups themselves. The objectives of such a plan would be disintegration of the political and social institutions, of culture, language, national feelings, religion and the economic existence of national groups, and the destruction of the personal security, liberty, health, dignity, and even thelives of individuals selonging to such groups. ${ }^{16}$

The problem with the application of such conceptualisation is that, as noted, the Australian state did not aim, at the time of dispossession, to physically 'annihilate the groups themselves'. Short-term and long-term policies towards A borigines in the nineteenth century were developed and implemented by pragmatic governments with severely limited resources. The aim was to establish control over land and to deter and punish resistance with the least financial cost to the state, including indirect sanction of settler violence. Within such a polity there were options for the physical survival of some A boriginal peoples. The limits to state action in A ustralia are clarified by consideration of the possible, made evident through examination of $\mathrm{N}$ azi policies that aimed to destroy both the physical existence of Jews and their right to be considered, and to consider themselves, as human.

Under Nazi rule, ideological goals took priority over the pragmatic, the one-sided war against unarmed Jews over the military confrontation with Soviet Russia and the western allies. Emil Fackenheim has written that:

The Nazi genocide of the Jewish people did not masquerade under an ideology. The ideology was genuinely believed. This was an 'idealistic' genocide to which war aims were ... sacrificed. The ideal was to rid the world of Jew as one rids oneself of lice. It was also, however, to 'punish' the Jews for their 'crime', and the crime in question was existence itself. Hitherto such a charge had been directed only at devils. Jews had now become devils as well as vermin. ${ }^{17}$

14. Raymond Evans 1999, 'Kings in brass crescents', in Raymond Evans, Fighting words: writing about race, University of Queensland Press, St Lucia: 180-200.

15. Andrew Markus 1994, A ustralian race relations 1788-1994, Allen \& Unwin, Sydney: ch 2.

16. Barta 'After the Holocaust': 154.

17. Emil Fackenheim 1979, Forew ord, in Yehuda Bauer, The Jewish emergence from powerlessness, University of Toronto Press, Toronto: 7; see also Yehuda Bauer 1994, 'The significance of the Final Solution', in David Cesarani (ed.), The Final Solution: origins and implementation, Routledge, London: 300-9. 
Some Jewish communities sought to survive by making themselves indispensable to the German war effort, only to be tragically disappointed. Despite the establishment of significant industrial works in many ghettos, contribution to the war succeeded in buying only limited time. In the face of Germany's severe and growing labour shortage, most of the Polish ghettos were emptied during 1942 and early 1943 and their populations murdered. The remnant population of the last major ghetto (Lodz) was deported to A uschwitz in A ugust 1944. Further, not only was a significant labour source exterminated but also scarce railway rolling stock was used to transport Jews to the death camps at times crucial for the conduct of the war on the eastern front.

There was nothing that Jews could do to avoid death - they could not change their 'behaviour' to accommodate the demands of the Nazi regime. The problem stemmed not from their resistance, nor from their unwillingness to change. Whatever their outward behaviour, the one consideration was that they were Jews, not to be permitted to exist in the living space of the German people, which came to be defined as all of Europe and then regions beyond. For Hitler and his henchmen J ews were considered to embody an evil, malevolent force, forever in struggle with the German. According to the principles of Nazi social Darwinist thought, the struggle between the German and Jewish life force could only have one outcome - the total victory of one over the other. Such belief justified the hunt for Jews throughout the Nazi empire, even to the distant shores of northern A frica.

In this race war the Germans went beyond the needs of physical extermination, enacting a charade in which selected numbers of Jews were allowed to live temporarily to serve the function of demonstrating their status as life unworthy of life. The degradation and suffering of the Jewish captives was seen as a daily affirmation of the superior life force of the German master race.

In a number of camps Jews were required to perform senseless work in conditions designed to maximise suffering. One prisoner recalled:

In our wooden shoes we were chased by blows from rods into a corner of the field and had to fill sometimes our caps, at other times our jackets, with stones, wet sand or mud, and, holding them with both hands and running under a hail of blows, bring them to the opposite corner of the field, empty the stuff, refill it and bring it back to the opposite corner, and so on. A gauntlet of screaming SS men and privileged prisoners, armed with rods and whips, let loose on us a hail of blows. It was hell. ${ }^{18}$

Sara Grossman recalled her first experience of Auschwitz, being flung from a cattle truck and left standing on the selection ramp, approaching the SS officers determining the immediate fate of each individual by a gesture of the hand, to the left or the right:

I saw columns of women marching on the other side ... who were half naked, shaven heads, stretching out their arms. 'Food, food. Give men your bread!' Screaming, shouting. I was overwhelmed. I thought that I found myself in an asylum, in a madhouse, in a place with only crazy people. ${ }^{19}$

18. Daniel Goldhagen 1996, H itler's willing executioners: ordinary Germans and the H olocaust, A bacus, London: 294.

19. Dwork and Pelt, A uschwitz: 346. 
Unlike the situation in the ghettos, the death camp experience was of a magnitude beyond human understanding. The moral philosopher Raimond Gaita argues that what made the death camps distinctive was not their 'horrific efficiency', but the unprecedented assault 'on the preciousness of individual human beings' ${ }^{20}$ The N obel Laureate, survivor of A uschwitz, Elie Wiesel, has written:

The enemy tried to create a society, a framework, a history without Jews. Substituting himself for God, the SS man sought to recreate the universe in his own image. His endeavour was ontological. It was of a sociological nature ... One was not allowed to look into the eyes of an SS man, for the SS man was God, and you cannot look into the face of God, just as you cannot look into the face of the Angel of Death. The objective of the enemy was, actually, to erect a new system, with new concepts of the absolutes: Time and Space, and even to create a new species ... Time was different. One could age in a matter of days, if not hours. Men and women looked alike, they were neither old nor young, neither perceptive nor obtuse, neither heal thy nor sick. They were neither rich nor poor, they were something else. They had no name, no face, no identity, no future. They did not laugh, nor did they weep. They did not smile, nor did they curse. They lived and suffered in a universe beyond our own, a universe dominated and willed by death ... Inside that universe, hope and fear, triumph and defeat, had different meanings. A piece of bread was more important than the rarest work of art. In fact, a piece of bread was a work of art. A spoonful of soup elicited a deeper yearning than a bride does from the groom. No poet, no novelist, no artist could demonstrate more talent in his work than an inmate moved in describing what used to be a meal at home. The waiting for the daily portion of potatoes was a mystical experience. ${ }^{21}$

The post-dispossession period marks a second phase in the history of contact, a time when A boriginal people were living, to varying extent, in the European world. In this period some parallels may be drawn with the treatment of Jews in Nazi Germany.

Australian and German governments envisaged a time when the state would be free of the despised racial 'other'. The basis of policy was the definition of A boriginal and Jewish people in pseudo-racial terms, in terms of the 'race' of grandparents and in both cases categories of mixed descent (half-caste, quarter-caste, quadroon, M ischlinge of the first and second degrees) were established in law, with significant legal consequences. Both peoples witnessed the formal withdrawal of citizenship rights, including welfare benefits, although in Australia it was more often the case that future rights to benefits were denied at the time of establishment of rights than rights al ready exercised were withdrawn. Both peoples experienced restrictions on freedom of movement and the requirement to reside in specified locations - reserves in the one case, ghettos in the other. A boriginal people were also prevented in some States from entering towns without permits, or required to move on by local policy enforced by police. ${ }^{22}$ Some

20. Raimond Gaita 1999, A Common H umanity, Text Publishing, Melbourne: 141.

21. Elie Wiesel c1988, 'Some questions that remain open', in A sher Cohen et al., Comprehending the H olocaust: historical and literary research, P. Land, Frankfurt am Main: 301-2.

22. Markus, Race relations, ch 5. 
Aboriginal people were confined in closed institutions - including children's homes, prisons, Queensland's Palm Island reserve - but in the context of the under-resourced A boriginal programs the extent of near-total control witnessed under German rule was not the typical experience of Aboriginal people.

The issue that has most recently engaged the attention of historians and the Australian public is the removal of A boriginal children, the 'stolen generations', often cited with reference to the United Nations convention which, as noted, specifies the removal of children as a distinct category of genocide. ${ }^{23}$

In my view the debate that has erupted over the removal of children has diverted attention from an issue of central importance. Policies of child removal should not be seen in isolation, as they often are - child removal was but one of the integral components of a clearly articulated government policy in the first two-thirds of the twentieth century.

In the first decades governments looked forward to the date when Australia would be racially pure, home only to the White race. Immigration of non-Europeans was barred and those al ready resident would be encouraged to return to their places of origin. Employment in the sugar and furniture industries and the occupation of hawking, to name the most prominent of vocations affected, was restricted on racial criteria with the intent of making life in A ustralia impossible. Targeted groups were al so denied citizenship rights and welfare benefits under legislation enacted in the first decade of the century.

The assumption informing policy was that the number of non-European residents would dwindle and A boriginal people would 'die out'. Governments did not actively facilitate this process by mass killing, but little money was made available to meet A boriginal needs, particularly in outback regions where 'full-blood' populations were predominant. ${ }^{24} \mathrm{~A}$ comparison can be made with the fourth stage of the Holocaust, the ghetto period, when deliberate policies to limit food and withhold medical supplies led to a rapid increase in mortality.

In Australia this issue has yet to be studied systematically; we need to know more about government treatment of the dispossessed, including policies in the nineteenth century. There is much evidence, however, that in the first four decades of the twentieth century (and in earlier periods) governments pursued a policy of 'calculated neglect' in remote regions, failing to provide for Aboriginal needs at a level that was considered adequate for white communities. The $\mathrm{N}$ azi regime had a hierarchical scale, determining the physical needs of populations on a racial basis - Aryans at one level, Slavic peoples

23. On the practice of child removal and contemporary debate, see Peter Read 1982, The stolen generations: theremoval of A boriginal children in N ew South Wales, 1883-1969, Government Printer, Sydney; Coral Edwards and Peter Read (eds) 1989, The lost children: thirteen A ustralians taken from their A boriginal families tell of their struggle to find their natural parents, Doubleday, Sydney; Peter Read 1999, A rape of the soul so profound: the return of the stolen generations, Allen and Unwin, St Leonards; A nna H aebich 2000, Broken circles: fragmenting Indigenous families 1800 2000, Fremantle Arts Centre Press, Fremantle; Robert Manne 2001, 'In denial: the stolen generations and the Right', A ustralian Q uarterly Essay, no 1, Melbourne.

24. Andrew Markus 1990, Governing savages, Allen \& Unwin, Sydney: ch 1. 
much further down, Jews at the bottom on starvation rations. There were some similarities in Australia.

In the north many mission stations were inadequately resourced to care for their populations, yet this situation was tolerated. In 1929 a national scandal erupted when it was revealed that Aboriginal people were dying of beri-beri and scurvy at the Hermannsburg mission; this led to donations of food in the south, but the public soon lost interest. Medical problems - such as yaws, tuberculosis, trachoma, leprosy, venereal disease - were often drawn to government attention, without evoking much concern, except in the case of diseases which threatened to spread to the white population. ${ }^{25}$ Those suffering such diseases were placed in controlled institutions, islands being a preferred destination, and then given minimal care.

Once it came to be accepted that the Aboriginal population would not die out, attention turned to solution through assimilation. This policy was first implemented in the removal of light-skinned children, many of whom were taken from their parents, educated in White-run institutions and then placed in the workforce. The impact of the policy on Aboriginal populations was devastating, not to be measured solely by the number of children removed (a preoccupation of some commentators) but also by the impact on those who remained behind - in a population distinguished by the strength and extent of its kinship networks. There was not only the effect of personal loss on parents, siblings, extended families and friends; there was also insecurity faced by those left behind, not knowing who would be next, and the brutal nature of the relationship with those in authority. Removal of children betokened a negation of Aboriginal lifeways, a 'rape of the soul so profound' in Kevin Gilbert's eloquent phrase - a phenomenon that resonates with the experiences of Jews under Nazi rule. Gilbert wrote:

The real horror story of Aboriginal Australia today is locked in police files and child welfare reports. It is a story of private misery and degradation, caused by a complex chain of historical circumstances, that continues into the present ... A boriginal Australia underwent a rape of the soul so profound that the blight continues in the minds of most blacks today. It is this psychological blight, more than anything else, that causes the conditions that we see on reserves and missions. ${ }^{26}$

Following World War II, policies of absorption were given wider focus - the assimilation of all Aboriginal people over the course of several generations. The aim was avowedly to bring an end to the existence of a distinctive Aboriginal way of life and identity. In 1937 the Western Australian Chief Protector, A.O. N eville, advocated the merging of 'half-castes' so that in time to come it will be forgotten 'that there were any Aborigines in Australia'. ${ }^{27}$ One of the chief architects of post-war policy, Paul Hasluck, explained in 1952:

Assimilation ... means, to my mind, that we expect that, in the course of time, all persons of aboriginal blood or mixed-blood in Australia will live in the same man-

25. See, for example, Markus, Governing savages: 16-20, 85-6; Peter Biskup 1973, N ot slaves, not citizens, University of Queensland Press, St Lucia: 111-16; Rosalind Kidd 1997, The way we civilise, University of Queensland Press, St Lucia: ch 4.

26. Kevin Gilbert 1977, Living Black: Blacks talk to K evin Gilbert, Penguin, Ringwood: 2-3.

27. Quoted in Manne 2001: 40. 
ner as white Australians do, that they will have full citizenship and that they will, of their own desire, participate in all the activities of the Australia community. Full assimilation will mean that the aboriginal shares the hopes, the fears, the ambitions and the loyalties of all other Australians and draws from the A ustralian community all his social needs, spiritual as well as material. Whether biological assimilation goes hand in hand with cultural assimilation is a matter which time will reveal but my own guess would be that, if cultural assimilation occurs, mating will follow naturally. ${ }^{28}$

Such policies of assimilation were in total opposition to Nazi thinking on racial issues. Under the $\mathrm{N}$ azi regime Jewish children - irrespective of appearance - were to remain with their parents, to be killed. From mid-1941, following the invasion of the Soviet Union, children were murdered by shooting, al ong with other members of their families and communities. Following the establishment of the death camps in 1942 children were deported along with their parents and gassed to death on arrival. While at some camps adults fit for physical labour were spared temporarily to work as slave labourers, children were immediately killed with but rare exception, one being those spared to become subjects for medical experimentation.

A number of famous cases of child removal survived the attempts of the Nazi regime to hide traces of their crimes. In the Lodz ghetto the Jewish authorities, under the leadership of Chaim Rumkovsky, were instructed in 1942 to hand over all children under the age of ten. A midst fierce debates, and given the option of handing over children or of leaving the task of rounding up to Nazi thugs, the authorities complied. Pictures survive of children waiting for deportation, separated from mothers and siblings by wire fencing. ${ }^{29}$ During deportations from the Warsaw ghetto in the same year, the order was given to empty the orphanages. In one case the renowned child educator, Janusz Korczak, dressed his charges as if for a country outing and led a march of those entrusted to his care through the ghetto to the cattle trucks assembled at the railway yards, the children ranged in rows of four, dressed in their Sunday best, clutching flasks of water and their favourite books or toys. On arrival at the Treblinka death camps the children were immediately killed. ${ }^{30}$

Not content with the large numbers exterminated, the Nazi authorities searched remote areas of their empire for children in hiding, some in monasteries and church-run orphanages. In many countries those daring to hide children faced a death penalty if caught and many met this fate. ${ }^{31}$ Of the six million Jews killed in the Holocaust it is estimated that over one million were children.

This comparison is not intended in any way to diminish the suffering of A boriginal children and their kin. It is, however, important to differentiate experiences, not to lump all under the broad category of genocide. After the physical destruction of a life

28. Paul Hasluck 1953, N ative welfare in A ustralia : speeches and addresses, Paterson Brokensha, Perth: 56-7.

29. Michael Bernbaum (ed.) 1997, W itness to the H ol ocaust, HarperCollins, New York: 84-6; Chuck Lawliss c1994, ... and God cried: The H olocaust remembered, JG Press, N ew York.

30. Israel Gutman 1994, Resistance: the W arsaw Ghetto uprising, Houghton Mifflin, Boston: 139; Gutman (ed.), Encyclopedia of the H ol ocaust: 818.

31. See, for example, Eva Fogelman c1994, C onscience and courage : rescuers of Jews during the H olocaust, Anchor Books, New York. 
there is nothing temporal. A ssimilation of an individual may destroy sense of self, obliterating an individual's identity. But it does not necessarily do so. The experiences of some were mediated by the inefficiencies of bureaucracy, the gulf between intent and reality. Some were placed in the care of loving people. Not all suffered such mental trauma as to block return to what they had once been or were in the process of becoming through growth and maturation. For many there remained the prospect of escape, physical and mental.

Was there genocide committed in Australia? The answer rests largely on the definition used. I have argued that 'ethnocide' and 'genocide' are related but conceptually distinct phenomena. Others would not make such a distinction. Thus Robert Manne writes that 'for many writers ... it is not killing which is at the core of the concept of genocide but the desire and the decision to weed from the garden of humankind a people deemed by others not fit to live' - and has developed his analysis based on such an understanding. ${ }^{32}$

In terms of the definitions here adopted, the period of dispossession meets some of the criteria of genocide, with qualifications based on regional variation, limits to the extent of direct killing, and the varying degree of direct government involvement in the process of physical destruction. In the early colonial period conceptualisation of conflict in terms of limited warfare may be more applicable than genocide. However this issue is resolved, actions did not extend to the scale of a holocaust.

The policies of calculated neglect that characterised treatment of A boriginal people in remote areas and in force in the first four decades of the twentieth century (and earlier periods) are also candidates for conceptualisation as genocide. It is no accident that the dating of such policies coincides with the height of the White Australia policy, which aimed at racial purification and exclusivity. But such practices were of less force in the more heavily populated regions of the country and while there is evidence of the 'inflicting on the group conditions of life calculated to bring about its partial physical destruction', 'sel ective mass killing' occurred but was atypical.

The strongest case is to be made for ethnocide, the attack on Aboriginal ways of life, culture and identity, central to the enterprise of British (and other forms of) imperialism - a case which seems to be beyond question in the context of dispossession, most clearly evident in state-sanctioned missionary policy and the removal of children. In the early assimilation period it was the openly declared policy of governments to promote the disappearance of the A boriginal people as a distinct racial and cultural entity. It was the expectation of policy makers that in generations to come the only vestige of A boriginality remaining would be that some members of the Australian population would be darker in skin colour, with some vague remembrance that once their forebears had

32. Robert Manne 2001, 'Responseto correspondence', Q uarterly Essay, no. 2: 126-7; Robert Manne 2001, 'In denial', Q uarterly Essay, no. 1. 
belonged to a different cultural group. It was within the framework of such thinking that the policies of child removal were sanctioned and maintained.

\section{Acknowledgments}

The final version of this paper was developed after attendance at the Academy of Social Sciences in Australia workshop on 'The Genocide Effect', convened by Simone Gigl iotti and A. Dirk Moses, held at the University of Sydney, 4-5 July 2001. I gratefully acknowledge the opportunity to participate in the workshop.

\section{References}

Barta, Tony 1985, 'A fter the Holocaust: consciousness of genocide in Australia', A ustralian Journal of Politics and History, 31(1): 154-61.

Bauer, Yehuda 1994, 'The significance of the Final Solution', in David Cesarani (ed.), The final solution: origins and implementation, London, Routledge: 300-09.

__ 2001, Rethinking the H olocaust, New Haven, Yale University Press.

Bernbaum, Michael (ed.) 1997, W itness to the H olocaust, New York, HarperCollins.

Biskup, Peter 1973, N ot slaves, not citizens, St Lucia, University of Queensland Press.

Chalk, Frank and Kurt Jonassohn 1990, The history and sociology of genocide, New Haven, Yale University Press.

Charny, Israel (ed.) 1999, Encyclopedia of genocide, Santa Barbara, ABC-Clio.

Clendinnen, Inga 2001, 'First contact', in Q uarterly Essay, 2: 106.

Dwork, Deborah and Robert Jan van Pelt 1996, A uschwitz: 1270 to the present, New York, WW N orton.

Edwards, Coral and Peter Read (eds) 1989, The lost children: thirteen A ustralians taken from their A boriginal families tell of the struggle to find their natural parents, Sydney, Doubleday.

Evans, Raymond 1999, 'Kings in brass crescents', in Raymond Evans, Fighting words: writing about race, St Lucia, University of Queensland Press.

Evans, Ray and Bill Thorpe 2001, 'The massacre of history', The A ge, 7July, Saturday Extra:1, 6.

Fackenheim, Emil 1979, Foreword, in Yehuda Bauer, The J ew ish emergencefrom powerlessness, Toronto, University of Toronto Press.

Fogelman, Eva 1994, Conscience and courage: rescuers of Jews during the Holocaust, $\mathrm{N}$ ew York, Anchor Books.

Friedlander, Saul 1997, N azi Germany and the Jews: the years of persecution 1933-39, London, Weidenfeld \& Nicolson.

Gaita, Raimond 1999, A common humanity, Melbourne, Text Publishing.

Gilbert, Kevin 1977, Living Black: Blacks talk to Kevin Gilbert, Ringwood, Penguin.

Gilbert, Martin 1987, The H olocaust, London, Fontana.

Goldhagen, Daniel 1996, Hitler's willing executioners: ordinary Germans and the H olocaust, London, A bacus.

Gutman, Israel (ed.) 1990, Encyclopedia of the H olocaust, N ew York, Macmillan.

__ 1994, Resistance: the W arsaw G hetto uprising, Boston, Houghton Mifflin. 
Haebich, Anna 2000, Broken circles: fragmenting Indigen ous families 1800-2000, Fremantle, Fremantle Arts Centre Press.

Hasluck, Paul 1953, N ative welfare in A ustral ia: speeches and addresses, Perth, Paterson Brokensha.

Kidd, Rosalind 1997, Theway we civilise, St Lucia, University of Queensland Press. Lawliss, Chuck c1994, ... and God cried: the H olocaust remembered, N ew York, JG Press

Manne, Robert 2001, 'In denial: the Stolen Generations and the Right', Q uarterly Essay, 1. 2001, 'Response to correspondence', Q uarterly Essay, 2: 126-7.

Markus, Andrew 1990, Governing savages, Sydney, Allen \& Unwin. 1994, A ustralian race relations 1788-1994, Sydney, Allen \& Unwin.

Moses, A. Dirk 2000, 'A $n$ antipodean genocide? The origins of the genocidal moment in the colonisation of Australia', Journal of Genocide Research, 2(1): 89-106.

Novick, Peter 1999, The H olocaust in A merican life, Boston, Houghton Mifflin.

Read, Peter 1982, The Stolen Generations: the removal of A boriginal children in N ew South Wales 1883 to 1969, Sydney, Govt Printer.

_ 1999, A rape of the soul so profound: the return of the stolen generations, St Leonards, Allen \& Unwin.

Tat, Colin 1999, Genocide in A ustralia, AIATSIS Research Discussion Paper no. 8, Canberra, AIATSIS.

Wiesel, Elie C. 1988, 'Some questions that remain open', in A sher, Cohen et al., Comprehending the H olocaust: historical and literary research, Frankfurt am M ain, P. Land.

Yahil, Leni 1990, The H olocaust: the fate of European Jewry, Oxford, Oxford University Press, English edition. 